\title{
To the Problem of Protection of Medium Voltage Instrument Transformers with Fuses: Analytical Research
}

\author{
${ }^{1}$ National Technical University "Kharkiv Polytechnic Institute", Kharkiv, Ukraine \\ 2 ABM Amper Ltd., Kremenchuk, Ukraine \\ ${ }^{3}$ KPB Intra s.r.o., Bučovice, Czech Republic
}

Yevgen Bajda ${ }^{1}$ (D) Oleksandr Grechko ${ }^{1}$ (D), Viktor Buhaichuk² (D), and Robert Knápek ${ }^{3}$

Article History
Received:
29 September 2021
Accepted:
06 November 2021
Published online:
30 December 2021
Keywords
Medium Voltage
Instrument
Transformer;
Fuse;
Voltage Transformer
Protection;
Instrument
Transformer Primary
Winding Current

\begin{abstract}
Introduction. In the medium voltage power grid of $6-35 \mathrm{kV}$, there is a problem of protecting voltage instrument transformers. This is due to the insufficiently effective level of their protection with fuses. Recently, there have been more and more reports of accidents associated with the failure of voltage instrument transformers not only in Ukraine, but also abroad. The issue of conducting an analytical study of the problem of protection of medium voltage instrument transformers by fuses is relevant. Goal. Investigation of designs and characteristics of fuses for medium voltage instrument transformers to improve the efficiency of their protection. Results. The article shows that protection of medium voltage instrument transformers with epoxy insulation is often provided by fuses, in which the nominal current of the fuse-link is significantly higher than the maximum permissible long-term current of the primary winding of the instrument transformer. A comparative analysis of the current values of the primary winding of medium voltage instrument transformers with the values of the rated currents of the fuselinks of fuses of various manufacturers presented on the Ukrainian market is carried out. The design features and technical characteristics of fuses for medium voltage instrument transformers have been investigated in order to increase the efficiency of their protection. The advantages and disadvantages of the designs of fuses from various manufacturers have been investigated and it has been established that the design of fuses requires further improvement in order to increase the efficiency of protection of medium voltage instrument transformers. Discussion and prospects for further development. Since in Ukraine, the need for fuses to protect medium voltage instrument transformers is provided mainly by supplies abroad, a promising direction for further development in this direction is the creation of a domestic competitive design of a fuse and its introduction into production.
\end{abstract}

\section{INTRODUCTION}

One of the components of the medium voltage electrical network $6-35 \mathrm{kV}$ is a voltage instrument transformer (VIT) - a transformer in which the secondary voltage under normal conditions of application is almost proportional to the primary voltage and for the corresponding connection differs from it in phase by an angle which is approximately zero. Almost until the end of the 20th century transformers with oil insulation in a sealed container, such as single-phase NOM-6 or three-phase NAMI-6, NTMI-10 (Fig. 1), etc. as VITs were mostly used (in some places they are in operation to this day, and even manufactured), in the designs of which the oil medium was used both for direct insulation of the primary winding from the secondary one and for their cooling from overheating in case of emergencies such as temporary overloads, ferroresonance phenomena, etc. [1-0]. The disadvantages of VITs with oil insulation are:

- large dimensions of VIT due to the relatively low insulating properties of the oil;

- fire hazard of the oil environment;

- the need for periodic maintenance;

- the possibility of leakage with the corresponding consequences and others.

Since the mid-90s of the 20th century VIT manufacturers have increasingly used the so-called cast insulation in their designs, which has now almost

Corresponding author: oleksandr.grechko@khpi.edu.ua (Oleksandr Grechko)

(c) 2021 The Author(s). Published by O. M. Beketov National University of Urban Economy in Kharkiv Use permitted under Creative Commons Attribution 4.0 International (CC BY 4.0)

Cite as: Bajda, Y., Grechko, O., Buhaichuk, V., \& Knápek, R. (2021). To the problem of protection of medium voltage instrument transformers with fuses: Analytical research. Lighting Engineering \& Power Engineering, 60(3), 92-102. https:// doi.org/10.33042/2079-424X.2021.60.3.02 


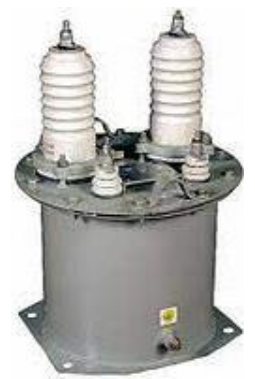

(a)

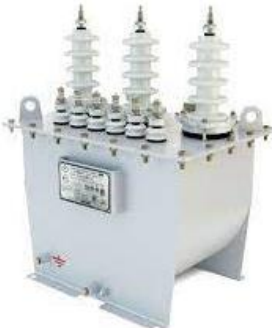

(b)

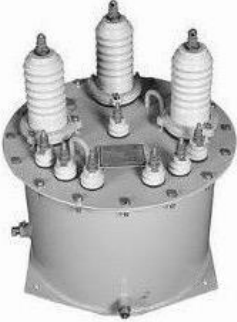

(c)
Figure 1. VITs with oil insulation: single-phase NOM-6 (a), three-phase NAMI-6 (b) and NTMI-10 (c)

completely supplanted oil VITs from the market. Cast insulation for transformers can be made either of foundry polyurethane elastomers (less often and, as a rule, for transformers for outdoor installation), or, most often, of epoxy compound (for transformers for indoor installation). Cast epoxy insulation is a mixture of components such as: thermosetting epoxy resin, hardener, powder filler (e.g., powdered quartz sand - to increase the thermal conductivity of the insulation, mechanical strength, etc.), and various additives (e.g., plasticizer - to reduce fragility, accelerator - to control the rate of polymerization, coloring - to provide the desired color). Due to both the properties of these components and the complex technological process of manufacture, VITs with epoxy insulation have significant advantages over oil ones, namely:

- reduced weight and overall dimensions due to higher insulating properties of epoxy insulation;

- increased mechanical strength of windings;

- no need for maintenance;

- longer service life;

- fire safety and others.

One of the important tasks that ensures the reliability of electricity transmission is the protection of VIT in case of emergency, which is manifested in the occurrence of overvoltages and resonant phenomena [9-12]. All overvoltages that occur in electrical networks can be divided into external and internal. The causes of overvoltages and resonant modes are extremely diverse: short circuit to ground; operation of the fuse in one of the phases; lightning strikes; disconnection of transformer idling, etc. The most common cause of surges is a short circuit of the phase to ground through an arc that appears or goes out, which can result in resonant phenomena and dangerous overvoltages [13-18].

Internal overvoltages and resonant phenomena in medium voltage lines are largely determined by the type of neutral grounding. Currently, there are four types of neutral grounding: insulated neutral (the most common option in domestic medium voltage networks); deafly grounded neutral; neutral grounded through the reactor and/or neutral grounded through a resistor (with high or low resistance). Studies show $[3,11,19]$ that the most promising in terms of reducing overvoltages and eliminating resonant phenomena are neutral grounding circuits through resistance and/or arc quenching reactor, but this requires changing the existing grounding scheme with readjustment of relay protection and not always possible (for example, when the line is connected to a power transformer, the windings of which are connected by a triangle). Another means of protection of VIT from emergency modes is the use of anti-resonant transformers, which are more complex in design and, accordingly, are less reliable $[1,2,10,13,20]$. In practice, there is a phenomenon when anti-resonant transformers, when switched on, themselves cause ferroresonance and displacement of the neutral beyond acceptable limits.

Therefore, the most reliable means of protection against emergency operation of both VITs separately and the equipment of the switchgear with busbars in general, are fuses with appropriate rated currents $[9,21-30]$.

For protection of VITs the fuses which are installed on the side of the primary windings of high voltage or separately on isolating basic insulators (Fig. $2 a, b$ ) in the distributing device or are directly mounted in a design of VIT (Fig. 2c) are applied. Such fuses are designed to protect VITs in the event of emergency modes, such as a short circuit on the secondary terminals. Other protective devices for protection of VITs are not applied in practice.

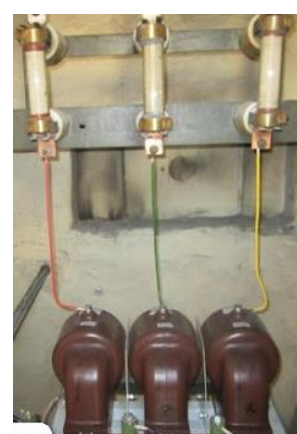

(a)

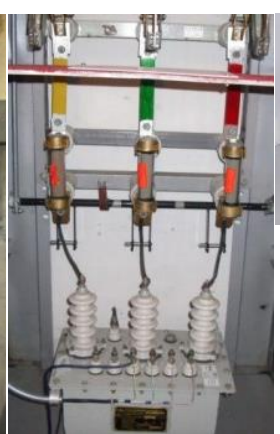

(b)

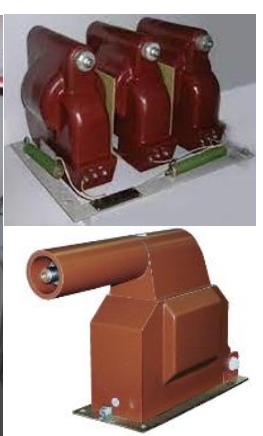

(c)
Figure 2. Examples of installation of fuses for protection VITs

\section{PROBLEM DEFINITION. JUSTIFICATION OF RELEVANCE}

It is traditionally believed that because the design of fuses is relatively simple (consists of a small number of parts, no moving parts with complex kinematics, etc.), they are one of the most reliable protection devices designed to protect electrical networks and equipment from overcurrents - overloads and short circuits. Most often, this statement is true - if the 
network has a powerful short circuit with a large peak value of the expected current, the fuse operates quickly, and due to the current-limiting effect, the current does not have time to reach its maximum value. This applies both to cases that occur in the low voltage network (up to $1000 \mathrm{~V}$ ) and in the medium $(6-35 \mathrm{kV})$ and high $(>35 \mathrm{kV})$ voltages networks. Another situation occurs in the case of small overload currents - there are examples when the fuses are unable to cope with a small increase in current in the protected circuit.

Fuses designed to protect low-voltage distribution networks up to $1000 \mathrm{~V}$ category $\mathrm{G}$ or L must switch off the circuit with overcurrent not immediately after its occurrence, but after a certain period of time, the duration of which is determined depending on the level of this overcurrent. According to the requirements of Standard [31] for fuses of category G with rated current $I_{n}$, the fusing of the fuseelement should not occur during a certain conventional time at current of $1.25 \cdot I_{n}$ (conventional nonfusing current), and at current 1.6 $I_{n}$ (conventional fusing current) fusing must happen obligatory within the same time. The value of the conventional time is defined in [31] depending on the rated current $I_{n}$ and can range from one to four hours. In particular, at $16<I_{n}<63 \mathrm{~A}$ the specified conventional time is 1 hour.

Fuses for medium-voltage and high-voltage circuits must meet the requirements of Standard [32] that apply to current-limiting fuses for various purposes, namely:

- for protection of power transformers;

- for protection of voltage instrument transformers (VITs);

- for protection of electric motors (AC voltage $3.6-36 \mathrm{kV})$;

- for protection of electrical equipment of power circuits of traction substations and rolling stock of railways (DC voltage 1.9-4 kV).

With regard to the values of conventional currents of non-fusing or fusing, or determining the duration of the conventional time of fusing, in the Standard [32] for fuses with voltage above $1000 \mathrm{~V}$ such values are not given.

Domestic Companies produce fuses of four types (Table 1):

- PKT - for protection of power transformers;

- PKN - for protection of voltage instrument transformers;

- PKE - for protection of electrical installations of excavators and mobile power plants;

- PKZ - for protection of power circuits of electric locomotives, electric trains and passenger cars.
Table 1. Characteristics of medium voltage fuses

\begin{tabular}{|c|c|c|c|c|}
\hline Parameter & PKT & PKE & PKN & PKZ \\
\hline $\begin{array}{l}\text { Rated } \\
\text { voltage, kV }\end{array}$ & & $6,10,35$ & & 3 \\
\hline $\begin{array}{l}\text { Rated current } \\
\text { of the fuse-link } \\
\text { (cartridge), A }\end{array}$ & & & not nor- & $2-40$ \\
\hline $\begin{array}{l}\text { Rated breaking } \\
\text { current, kA }\end{array}$ & & & & $<31.5$ \\
\hline
\end{tabular}

As it can be seen from Table 1, the values of the rated current of the fuse-link of medium voltage fuses for protection of VITs are not normalized. The reason for this is that the primary winding of the VIT, in the circuit of which the fuse is installed, has high resistance and, accordingly, the current flowing through the winding is quite small. The value of this current can be estimated by analyzing the technical data of VITs from different manufacturers. For a single-phase VIT with oil insulation type NOM-6 the following data are given:

- rated voltage $-6 \mathrm{kV}$;

- insulation resistance of windings at temperature of $20^{\circ} \mathrm{C}$ - not less than $300 \mathrm{M} \Omega$;

- maximum load of the secondary winding $400 \mathrm{VA}$.

So, the rated current according to the simplified formula is equal to:

$$
I=P / U=400 / 6000 \approx 66 \mathrm{~mA} \text {. }
$$

On the other hand:

$$
I=U / R=6 \cdot 10^{3} / 300 \cdot 10^{6} \approx 0,02 \mathrm{~mA} .
$$

In addition, the windings of VIT of this type are in the environment of the oil, which performs, as mentioned above, the cooling function. Therefore, even in the case of an increase in current through the primary winding (of course, to a certain level), it will not lead to failure of the winding and the transformer.

A completely different situation is observed in the case of VIT with epoxy insulation, the typical design of which is shown in Fig. 3. There is no source of additional cooling in the design of such transformers. Simultaneous long-term operation of VIT at maximum loads of the secondary winding with additional current increase through the primary winding in case of temporary overloads or ferroresonance phenomena can cause excessive overheating of VIT windings. Here, high heat-insulating properties of epoxy compound interfere with heat removal from the heated elements of VIT and promote the further overheating of cast insulation. As a result, in the absence of oxygen there is a thermal decomposition of superheated material with the formation of soot and gas evolution. 


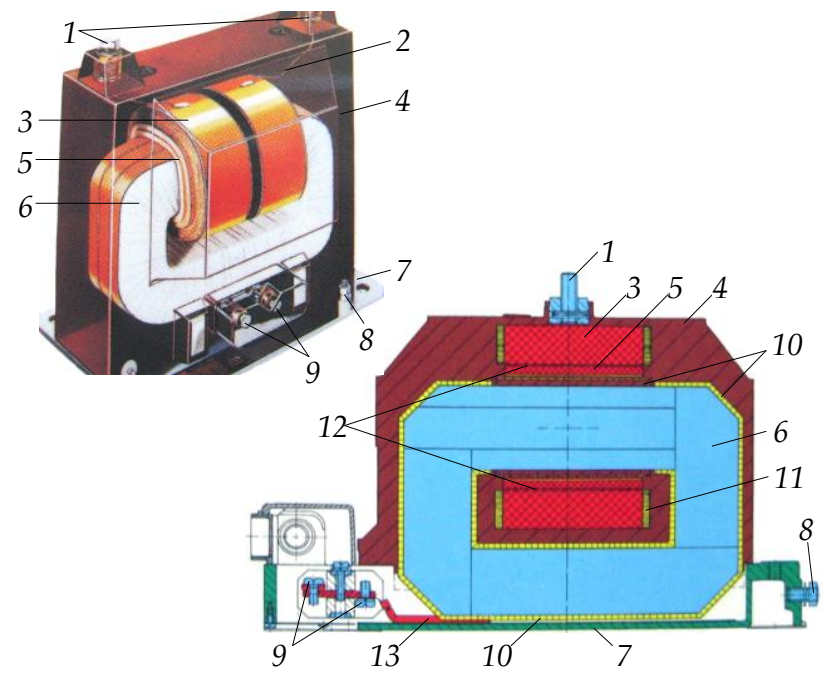

Figure 3. Typical design of medium voltage VIT with epoxy insulation: 1 - terminals of the primary winding; 2 - flexible taps of the primary winding; 3 - primary winding; 4 - epoxy insulation; 5 - secondary winding; 6 magnetic core; 7 - steel base; 8 - bolt of infringement; 9 terminals of the secondary winding; 10 - insulation of the magnetic core; 11 - insulation of the primary winding; 12 - insulation layer between the primary and secondary windings; 13 - flexible taps of the secondary winding

Soot reduces the electrical insulating properties of the compound and promotes further decomposition of the material, as soot itself is also an excellent thermal insulating substance. The result is the destruction of the compound under the influence of temperature and electrical breakdown, which ultimately leads to the destruction of VIT (Fig. 4).

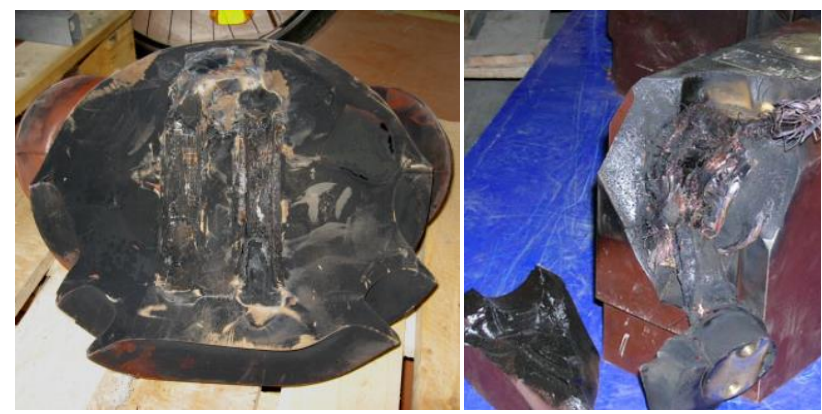

Figure 4. Examples of destruction of VIT with epoxy insulation

Recently, in the open information space there are more and more reports of accidents related to the failure of VITs not only in Ukraine but also abroad $[6,0,10,11,15,19,23]$. It should be noted that the presence of a relatively small number of publications on this issue and specific examples of emergencies does not indicate its absence or no-relevance, but indicates a certain reluctance on the part of both operators and manufacturers of VITs and fuses to cover it in real terms. Thus, the question of studying the problem of protection with fuse fuses of medium voltage instrument transformers is relevant.
The goal of the article is to study the designs and characteristics of fuses for medium voltage instrument transformers to increase the efficiency of their protection.

One of the parameters of VITs is the total nominal power of the devices, which can be simultaneously connected to the terminals of the secondary winding $-P_{2}, \mathrm{VA}$. The most common series of $P_{2}$ values is $10,50,100,150 \mathrm{VA}$. As the power $P_{2}$ increases, the VIT error increases accordingly, i.e. the highest VIT accuracy is observed in idle mode. Taking the value of the voltage on the primary winding at the level $U_{1}=6-35 \mathrm{kV}$, we can roughly estimate the value of the resistance $R_{1}$ of the primary winding of the VIT and the current $I_{1}$ flowing through it. The calculation results are given in Table 2.

Table 2. The results of calculation of current through the primary winding of VIT and its resistance

\begin{tabular}{ccccc}
\hline$U_{1}, \mathrm{kV} \rightarrow$ & 6 & 35 & 6 & 35 \\
\hline$P_{2}, \mathrm{VA} \downarrow$ & \multicolumn{2}{c}{$R_{1}, \mathrm{M} \Omega$} & \multicolumn{2}{c}{$I_{1}, \mathrm{~mA}$} \\
\hline 10 & 3.6 & 122.5 & 1.66 & 0.28 \\
50 & 0.72 & 24.5 & 8.33 & 1.43 \\
100 & 0.36 & 12.25 & 16.67 & 2.86 \\
150 & 0.24 & 8.2 & 25.0 & 4.28 \\
\hline
\end{tabular}

We conduct a comparative analysis of the obtained values of the primary winding current of VIT with the values of the rated currents of the fuselinks of different manufacturers on the market of Ukraine, as well as present their technical characteristics and design features to analyze the effectiveness of protection.

\section{DESCRIPTION OF THE DESIGN OF THE FUSE PKN 011-10 MANUFACTURED BY QUARTZ LLC, UKRAINE}

The only manufacturer of fuses in Ukraine for the protection of medium voltage electrical equipment for 6-35 kV is QUARTZ LLC, city of Zaporizhzhia. To protect the circuits of voltage transformers, this Company manufactures a fuse PKN 011-10, consisting of a fuse-element changed after operation, contacts and support insulators.

The fuse-element is non-detachable, but we mechanically destroyed it in order to conduct research and establish design features (Fig. 5). It should be noted that the design of the fuse-element was well known and consisted of the porcelain body 1 with metal caps 2 with rubber seals at both ends. Inside the structure on the insulating rod 3 there is the spirally wound conductive fuse-element 4 of different cross section, connected to two caps by flexible taps 5 . The entire interior of the housing is filled with fine-grained filler - quartz sand (which is not shown in Fig. 5), as is known, provides intensive 


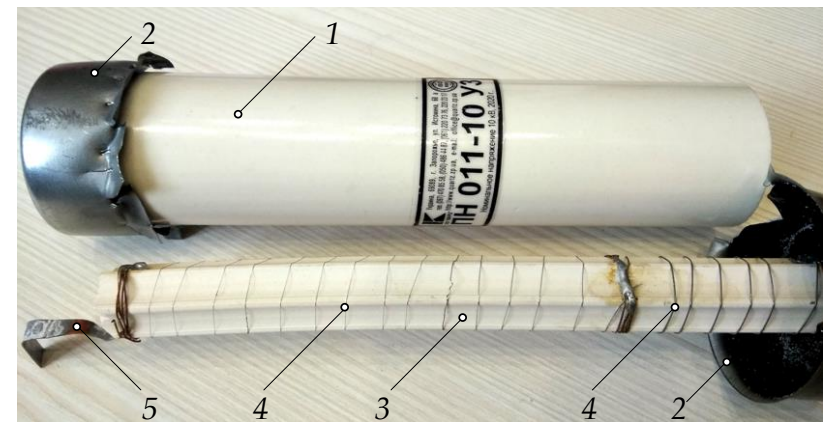

Figure 5. Design of the fuse-element of the fuse PKN 01110 manufactured by QUARTZ LLC

extinguishing of the electric arc at switching off emergency currents.

According to the technical data on the fuse PKN 011-10 fuses of this series allow long-term load current up to $0.5 \mathrm{~A}$. Indeed, it is also stated that the fuses of the PKN series are designed to protect voltage transformers (it is about instrument transformers, because to protect power voltage transformers series PKT is designed). The question arises - is a fuse with rated current $I_{n}=0.5 \mathrm{~A}$ able to protect medium voltage VIT with epoxy insulation?

In [19] it is noted that one of the main reasons for the high damage of voltage transformers is the complete lack of protection of voltage transformers at the terminals of the primary windings. Fuses of types PKN and PKT used for protection of voltage transformers are unsuitable as currents of operation of these fused considerably exceed maximum permissible long currents of primary windings of voltage transformers. Fuses operate after damage of voltage transformers, because the maximum allowable long-term currents are tens of milliamperes (see data in Table 2), while overcurrents flowing through the primary winding of voltage transformers at overvoltages, create current densities in unacceptable intervals of up to several tens of Amperes per $\mathrm{mm}^{2}$.

Thus, it can be argued with high probability that PKN series of fuses cannot be used to protect medium voltage VITs with epoxy insulation, in which the maximum allowable long-term currents of the primary windings are much lower than the rated current of the fuse that protects them.

\section{DESCRIPTION OF THE DESIGN OF THE PROTECTIVE SAFETY DEVICE 5GG.674 350.000 MANUFACTURED BY JSC SVERDLOVSK CURRENT TRANSFORMER PLANT, RUSSIAN FEDERATION}

A common device for protection of VIT with cast insulation is the use of so-called built-in protective safety devices type 5GG.674 350.000 manufactured by JSC Sverdlovsk Plant of Current Transformers, Russian Federation. Such devices are built directly into the design of VIT type ZNOL, ZNOLP, ZNOLPM, NOLP and are a collapsible structure (Fig. 6a), consisting of the textolite housing 1, closed on both sides by tips 4,5 . Inside the housing there is the working spring 6 (in the initial state it is erected), on the left side to which the movable rod 7 is attached. On the right side to the working spring with the left leg the resistor 9 type $\mathrm{C} 2-33-\mathrm{H}$ with the metal-dielectric conductive layer of power of 0.125 or $0.25 \mathrm{~W}$ and resistance 1.5 to $36 \Omega$ (depending on the type of VIT in which it is installed) is attached, which acts as a fuse-element. In turn, the right leg of the resistor 9 is attached to the bar 3 . When the resistor burns out, the working spring 6 operates (compresses), providing the necessary insulating gap to prevent the recurrence of the electric arc. The spring 8 is used to push out the movable rod 7 and to indicate the operation of the protective device. The design of the movable rod provides for the presence of the washer 2, which serves as a support for the spring pushing the rod (Fig. 6b).

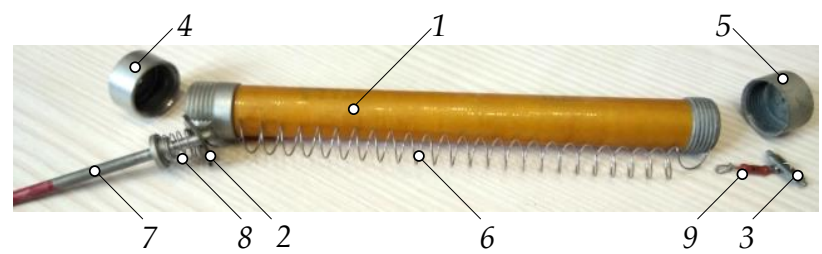

(a)

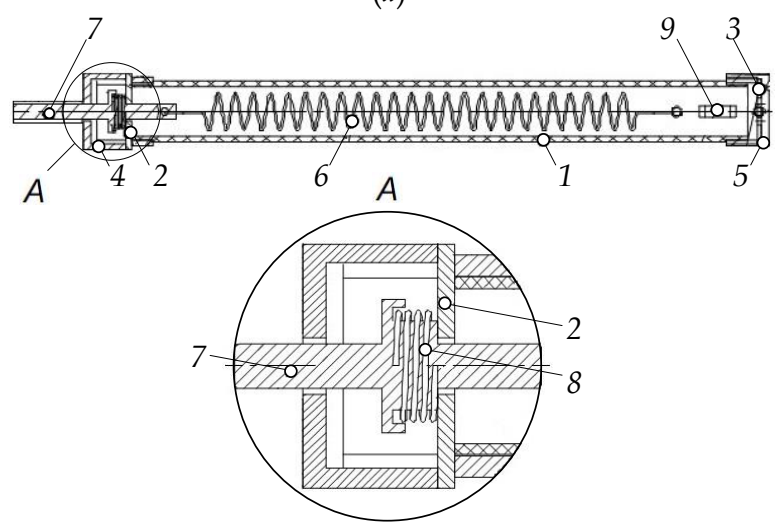

(b)

Figure 6. External view (a) and design (b) of the protective safety device 5GG.674 350.000 manufactured by JSC SCTP: 1 - housing; 2 - washer; 3 - bar for fastening of the resistor; 4, 5 - tips; 6 - working spring; 7 - rod; 8 - spring pushing out the rod; 9 - resistor

Such a protective device is a replacement design, i.e. after its operation it is possible to change both the failed resistor and the entire safety protection device.

In order for the protection device to operate, it is necessary that the current flowing through the resistor leads to its overheating and obligatory mechanical destruction in order to release the working spring. If the current value is insufficient, then only the resistor will heat up without destroying it. After 
analyzing the technical characteristics of the most common VITs, protected by safety devices 5GG.674 350.000 , it is possible to estimate the value of the maximum allowable long-term currents of the primary windings (Table 3).

Table 3. Some technical data of VITs protected by the safety device 5GG.674 350.000

\begin{tabular}{llllllll}
\hline & & & & & \\
\end{tabular}

As it can be seen from Table 3, a resistor with resistance of $11 \Omega$ with power of $0.25 \mathrm{~W}$ is used as a fuse-element everywhere. That is, the rated current through such a resistor in the nominal mode will be equal to

$$
I=\sqrt{P / R}=\sqrt{0,25 / 11} \approx 151 \mathrm{~mA}
$$

at the maximum allowable long-term currents of the primary winding in the range of 60-120 mA.

That is, it can be concluded that the protective safety device type 5GG.674 350.000 manufactured by JSC Sverdlovsk Current Transformers Plant is also not effective for protection of medium voltage VITs with epoxy insulation, because the maximum allowable long-term currents of primary windings of VITs are much lower than the rated current that will not lead to its overheating and mechanical destruction and will not cause operation of the safety device.

Another confirmation of this conclusion can be the data on the maximum allowable long-term currents of the primary winding for VIT $3-35 \mathrm{kV}$, which are given in [19] (Table 4).

Table 4. Maximum allowable long-term currents of the primary winding for VITs at voltage of 3-35 kV [19]

\begin{tabular}{cc}
\hline Voltage class, $\mathrm{KB}$ & $\begin{array}{c}\text { Maximum allowable } \\
\text { long-term currents of the } \\
\text { primary winding of VIT, mA }\end{array}$ \\
\hline 3 & 144 \\
6 & 115 \\
10 & 109 \\
35 & 49 \\
\hline
\end{tabular}

\section{DESCRIPTION OF THE DESIGN OF THE FUSE TYPE 187000 MANUFACTURED BY SIBA, GERMANY}

Among foreign manufacturers, in the catalogs of which there are fuses for protection of VIT, we can mention the SIBA Company, Germany. Fig. 7 shows the design of the Type 187000 fuse, consisting of the ceramic body 1 with diameter of approximately 8 $\mathrm{mm}$ and two nickel-plated brass tips 2, which cover the inner space of the fuse and to which the fuseelement 3 is electrically connected.

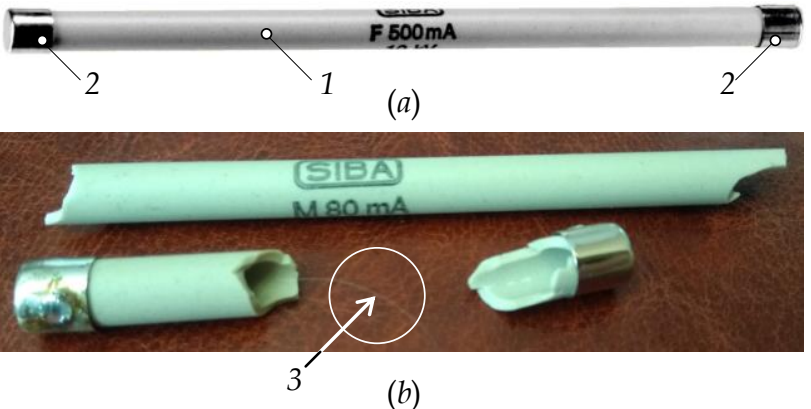

Figure 7. External view (a) and design (b) of Type 187000 fuse manufactured by SIBA: 1 - body; 2 - tips; 3 - fuseelement

The body of fuses voltage of $6 \mathrm{kV}$ is made with length of $120 \mathrm{~mm}$, for a voltage of $10 \mathrm{kV}-150 \mathrm{~mm}$. The fuse-element of the fuse is an extremely thin wire, the diameter of which could be determined only with an optical microscope manufactured by the German Company Carl Zeiss with 100 times magnification. The result of measuring the diameter of the fuse-element is approximately $d=30 \mu \mathrm{m}$ (Fig. 8).

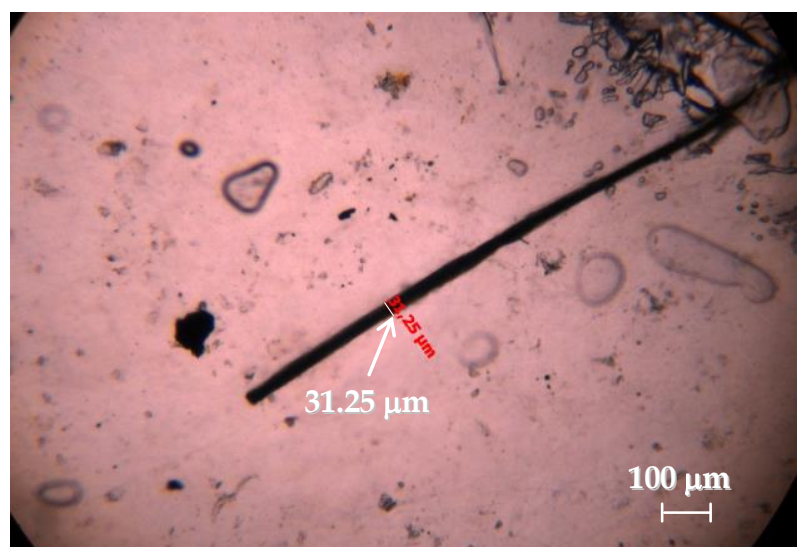

Figure 8. Result of measuring the diameter of the fuseelement of the SIBA fuse using an optical microscope

For research, the authors of the article had a fuse for $10 \mathrm{kV}$ with rated current of $80 \mathrm{~mA}$ (Fig. 7b). The resistance of such a fuse was $R=20 \Omega$, length $l=150$ mm. Knowing the values of $R, l, d$, the resistivity $\rho$ of the fuse-element is approximately calculated: 


$$
\rho=\frac{\pi \cdot d^{2}}{4} \frac{R}{l}=\frac{3.14 \cdot\left(30 \cdot 10^{-6}\right)^{2}}{4} \cdot \frac{20}{0.15} \approx 0.094 \cdot 10^{-6} \Omega \cdot \mathrm{m} .
$$

From reference values of resistivities of materials approximate values are characteristic of iron $\left(0.1 \cdot 10^{-6}\right.$ $\Omega \cdot \mathrm{m})$, different types of bronze $\left((0.095-0.1) \cdot 10^{-6}\right.$ $\Omega \cdot \mathrm{m})$ and brass $\left.(0.025-0.108) \cdot 10^{-6} \Omega \cdot \mathrm{m}\right)$, platinum $\left(0.107 \cdot 10^{-6} \Omega \cdot \mathrm{m}\right)$ and various steel grades $0.103-$ $\left.0.137) \cdot 10^{-6} \Omega \cdot \mathrm{m}\right)$. It should be noted that the material of the fuse-element was not attracted to the permanent magnet, so it can be argued that it is nonmagnetic. But the question of the exact determination of the material remains open.

A very important characteristic and one that distinguishes these fuses among others is the value of the rated current of the fuse-element, which is in the range from extremely small value of $32 \mathrm{~mA}$ to $2 \mathrm{~A}$. Time-current characteristics of fuses Type 187000 manufactured by SIBA are shown in Fig. 9.

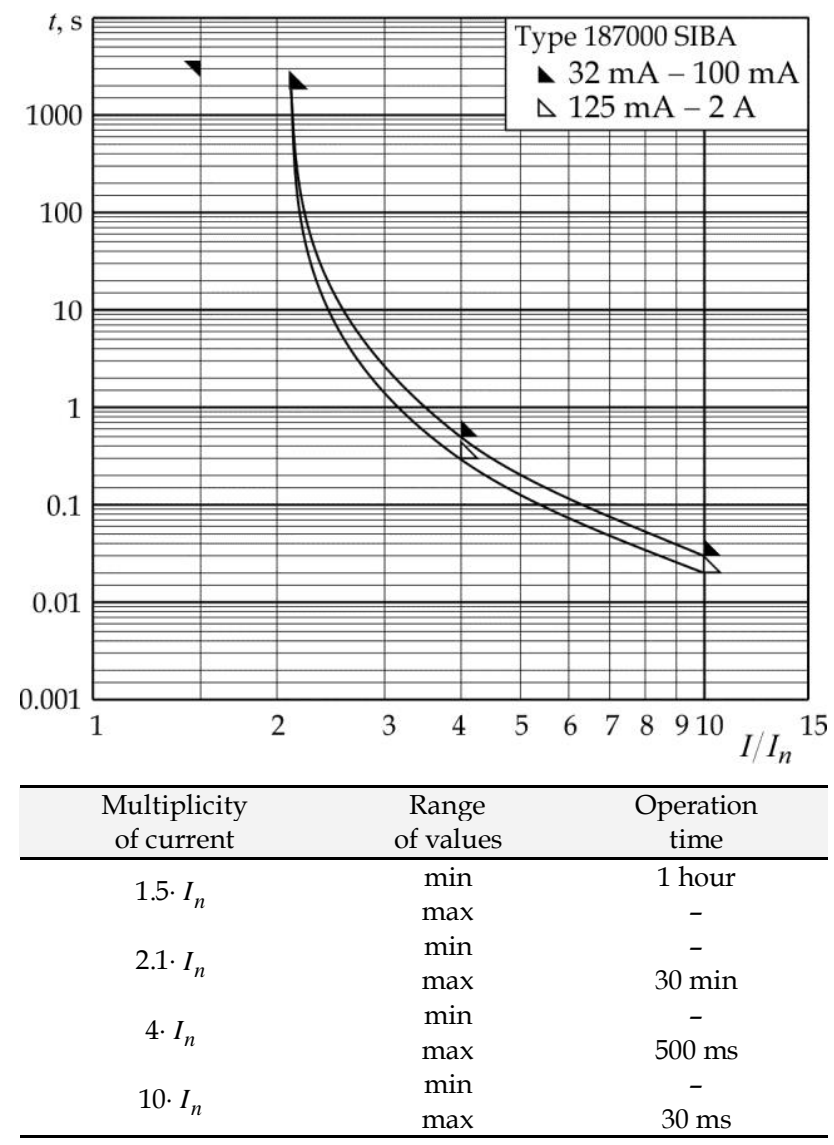

Figure 9. Time-current characteristic of Type 187000 fuses manufactured by SIBA (rated current of the fuse $I_{n}=32$ $100 \mathrm{~mA})$

Comparing the data of the time-current characteristic with the values of the maximum allowable long-term currents of the primary winding for VITs, given earlier, we can conclude that fuses Type 187000 manufactured by SIBA can serve as effective protection of medium voltage VITs with epoxy insulation. But a significant disadvantage of these fuses is their high cost and the ability to buy them only abroad, as they are in fact absent in Ukraine.

\section{DESCRIPTION OF THE DESIGN OF THE VPO 38-T0080 SAFETY FUSE MANUFACTURED BY KPB INTRA, CZECH REPUBLIC}

The original solution, which to some extent allows to increase the effectiveness of protection of medium voltage VITs, is the fuse VPO 38-T0080 manufactured by KPB INTRA, Czech Republic. Fig. 10 shows external view of the fuse $(a)$, its components (b) and sketch (c) according to the patent [33].

The key idea that formed the basis of the development of this fuse is the use of a low-voltage miniature fuse in the glass case, which is widely used to protect various household appliances, electrical equipment, electronics and more. It is known that such fuses have many advantages, among which we can highlight reliability, stability of protective characteristics, low value of rated current (up to $32 \mathrm{~mA}$ ), speed, low cost and availability. But for the successful use of these advantages of the low-voltage fuse as part of the high-voltage fuse, the development of a rather complex structure is required. Consider it in detail.

The fuse (Fig. 10b,c) consists of a ceramic housing 1 (diameter $20 \mathrm{~mm}$, length $320 \mathrm{~mm}$ ), on both sides of which metal tips 5 are installed sealing the interior space. Inside the housing to one of the tips the input contact hard copper tape 2 is soldered with one end, and the other end of the tape is soldered to the pad of tin 8 on the PCB 3. To the same pad 8 the first conductive holder 7 of the internal fuse 6 is soldered, and the opposite the conductive holder, in turn, is soldered to the pad 9. To the same pad 9 in the zone 10 one end of the charged working spring 4 is soldered, the other end of which is soldered to the output contact copper strip 11. Similarly, the other end of the strip 11 is soldered to the opposite tip 5.

In the normal mode, the current flows from the energy source on the conditionally first tip 5, then on the input contact strip 2, through the pad 8 on the conditionally first holder 7 , through the internal fuse 6 , on the conditionally second holder 7, through galvanically connected pads 9 and 10, further along the spring 4 , and along the output contact strip 11 to the conditionally second opposite tip 5 and then to the primary winding of the VIT.

In the event of an emergency current, the internal miniature fuse 6 operates - the current is interrupted. But the high voltage potential from the energy source remains present and now through the pad 8 and the thin path coming from it (see Fig. 10b), is applied to the conductive electrode 12 . The air gap between the electrode 12 with high potential and the pad with the zero potential 10 to which the 


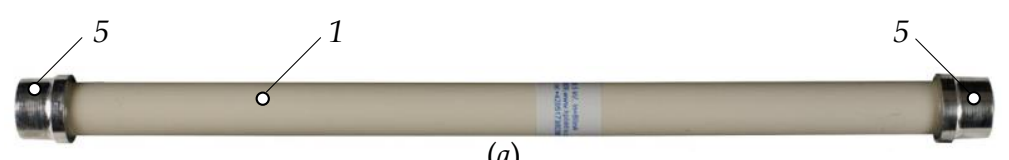

(a)
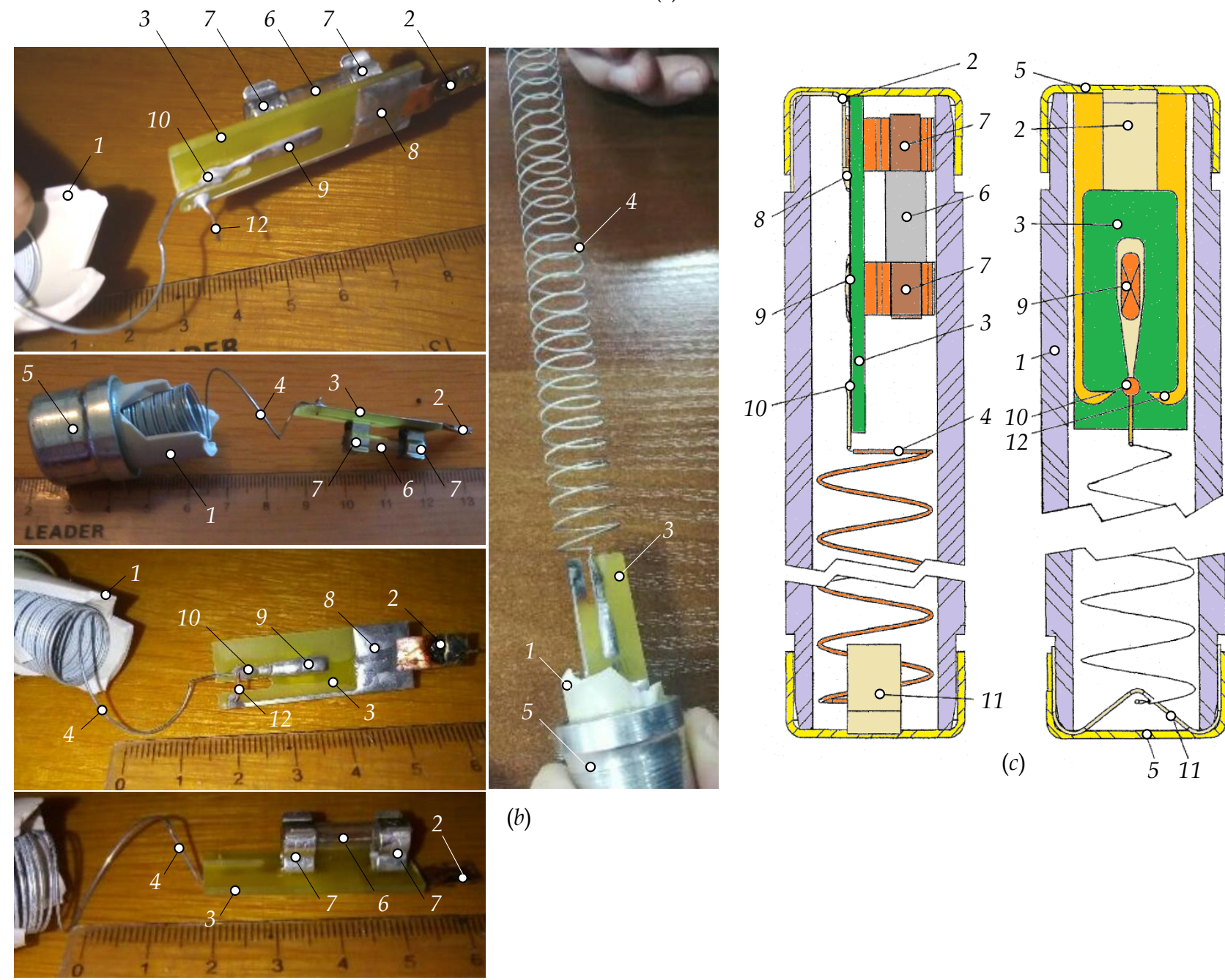

(b)

Figure 10. External view (a), design $(b)$ and sketch $(c)$ of fuse VPO 38-T0080 manufactured by KPB INTRA: 1 - housing; 2 - input contact tape; 3 - РCB; 4 - spring; 5 - tips; 6 - internal fuse; 7 - conductive holder of internal fuse; 8-10 - tin solder joints; 11 - output contact strip; 12 - conductive electrode

charged working spring 4 is soldered is $0.75 \mathrm{~mm}$ according to [33]. Thus, there is a breakdown of the air gap with the subsequent occurrence of an electric arc, which melts the tin on the pad 10 and releases the charged working spring - the electric arc is stretched and extinguished. As an option, [33] also proposes to fill the internal space of the fuse, for example, with sulfur hexafluoride $S F_{6}$, which will allow it to be used in a higher voltage network without changing the design of the fuse.

The effectiveness of protection of the fuse VPO 38-T0080 largely depends on both the parameters of the working spring and the protective characteristics of the internal miniature fuse. Miniature fuses in a glass housing $5 \times 20 \mathrm{~mm}$ type 521.006 manufactured by ESKA, Germany for rated current of $80 \mathrm{~mA}$ were installed in the investigated structures. It should be noted that this manufacturer also produces fuses in the same size, but for lower current - 32
$\mathrm{mA}$, type 521.002. Time-current characteristic of the fuses of the 521.000 series manufactured by ESKA is shown in Fig. 11.

Also, the effectiveness of protection of VITs by fuse VPO 38-T0080 depends on a clear and reliable operation of all components of the fuse (and there are many of them) according to the above algorithm. When making the fuse, it is necessary to ensure the set distance between the electrode and the pad to which the working spring is soldered. So, a certain disadvantage of this fuse can be considered a relatively complex design in the presence of a large number of components. Another disadvantage of the design is that after the operation of the internal miniature fuse, both its replacement and soldering of the working spring is possible only in special conditions, because the housing is hermetically sealed with tips using an airtight material. 


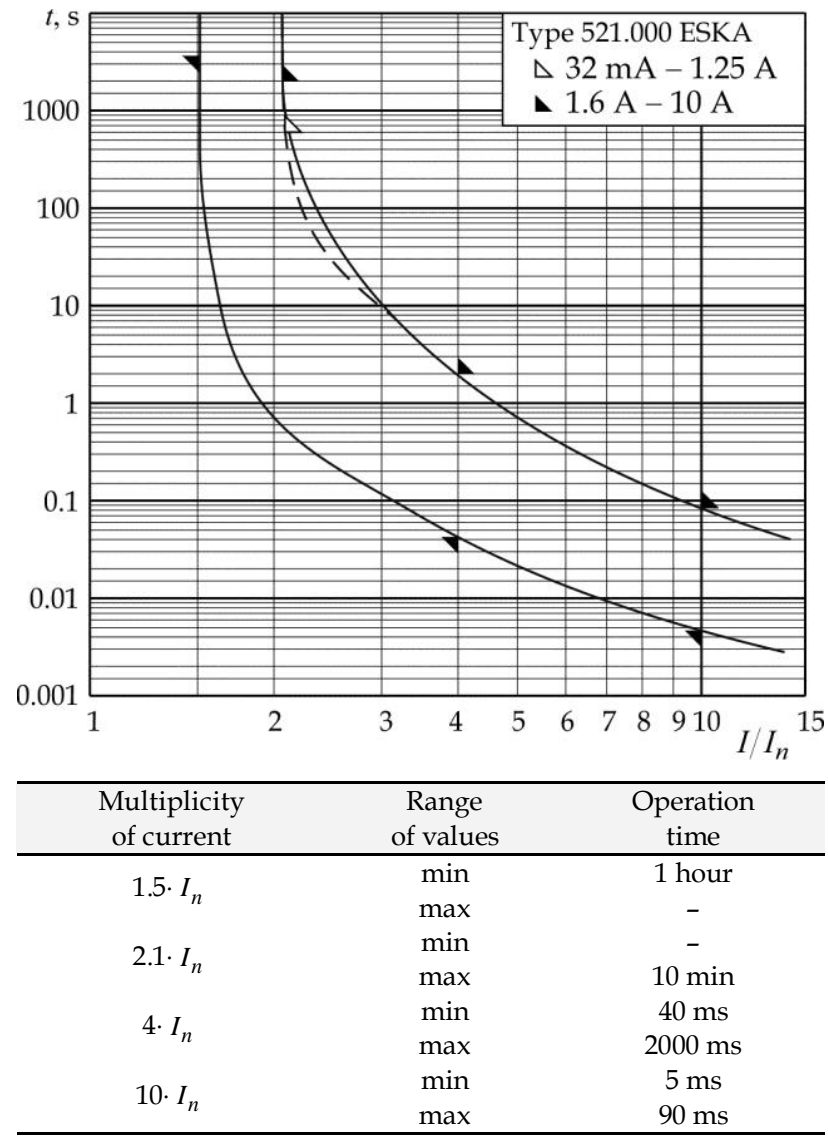

Figure 11. Time-current characteristic of the fuses of the 521.000 series manufactured by ESKA (rated current of the fuse $I_{n}=32-125 \mathrm{~mA}$ )

Despite these shortcomings, according to the authors, the design of the fuse VPO 38-T0080 provides effective protection of VITs with epoxy insulation, but also needs further improvement.

\section{CONCLUSIONS}

It is shown that in the medium voltage electric network of $6-35 \mathrm{kV}$ there is a problem of protection of voltage instrument transformers. This is due to the ineffective level of protection with fuses.

It was found that there are common cases when the protection of medium voltage instrument transformers with epoxy insulation is provided by fuses, in which the rated current of the fuse-link is much higher than the maximum allowable long-term current of the primary winding of the instrument transformer.

The design features and technical characteristics of fuses for medium voltage instrument transformers in order to increase the efficiency of their protection have been studied.

A comparative analysis of the values of the current of the primary winding of medium voltage instrument transformers with the values of the rated currents of the fuse-links of fuses of different manu- facturers, which are presented on the market of Ukraine, is carried out.

The advantages and disadvantages of fuse designs of different manufacturers have been studied, and it has been established that the design of fuses needs to be further improved in order to increase the efficiency of protection of medium voltage instrument transformers.

It is established that in Ukraine the needs for fuses for protection of medium voltage instrument transformers are provided mainly by supplies abroad, so a promising direction of further development in this direction is the creation of a domestic competitive design of fuses and its introduction into production.

\section{DISCLOSURE STATEMENT}

No potential conflict of interest was reported by the author(s).

\section{REFERENCES}

1. Tugai, Y.I., \& Tugai, I.Y. (2014). A combined method for study of ferroresonance processes in voltage transformer. In 2014 IEEE International Conference on Intelligent Energy and Power Systems (IEPS) (pp. 71-73). IEEE. https://doi.org/10.1109/IEPS.2014.6874205

2. Tugay, Y.I., Ganus, O.I., \& Starkov, K.O. (2016). The switching in voltage transformer. Technical Electrodynamics, 2016(5), 73-75. https://doi.org/10.15407/techned 2016.05.073

3. Zhurahivskyi, A.V., Kens, Y.A., Yatseyko, A.Y., \& Maslyak, R.Y. (2010). Ferroresonance processes in electrical networks $10 \mathrm{kV}$ with different voltage transformers. Technical Electrodynamics, (2), 73-78. http://previous. techned.org.ua/article/10-2/st9.pdf (in Ukrainian)

4. Ryzhkova, Y.N., \& Tsyruk, S.A. (2016). Ferroresonance suppression in distribution networks. In 2016 2nd International Conference on Industrial Engineering, Applications and Manufacturing (ICIEAM) (pp. 1-4). IEEE. https:/ / doi.org/10.1109/ICIEAM.2016.7911458

5. Jahagirdar, A., Thosar, A., \& Dhote, V.P. (2018). Study of high voltage inductive voltage transformer for transients and ferroresonance. In 2018 International Conference on Power, Energy, Control and Transmission Systems (ICPECTS) (pp. 174-180). IEEE. https://doi.org/10.1109/ ICPECTS.2018.8521570

6. Hanus, O., \& Starkov, K. (2021). Study of the nature of overvoltages in the electrical network arising from voltage transformers. Bulletin of the National Technical University "KhPI". Series: Energy: Reliability and Energy Efficiency, 1(2), 28-36. https://doi.org/10.20998/22240349.2021.01.05 (in Ukrainian)

7. Kaczmarek, M., \& Brodecki, D. (2021). Transformation of transient overvoltages by inductive voltage transformers. Sensors, 21(12), 4167. https://doi.org/10.3390/ s21124167 
8. McDermit, D.C., Shipp, D.D., Dionise, T.J., \& Lorch, V. (2013). Medium-voltage switching transient-induced potential transformer failures: prediction, measurement, and practical solutions. IEEE Transactions on Industry Applications, 49(4), 1726-1737. https://doi.org/10.1109/ TIA.2013.2258453

9. Dan, M., Zanotto, L., Gaio, E., Panizza, C., Finotti, C., \& Perna, M. (2021). Development and validation of a special protection system for internal fault in a highpower three-level NPC VSC. Energies, 14(18), 5937. https://doi.org/10.3390/en14185937

10. Zhurahivskyi, A.V., Kens, Y.A., Yatseyko, A.Y., \& Maslyak, R.Y. (2013). Multi-protection system power grids 6-35 Kv from ferroresonance processes. Technical Electrodynamics, (5), 70-76. http://previous.techned.org.ua/ 2013_5/st11.pdf (in Ukrainian)

11. Ganus, O., \& Starkov, K. (2003). Damageability of voltage transformers in regional electricity networks of JSC "Kharkovoblenergo" and measures to reduce it. Lighting Engineering \& Power Engineering, (1), 75-81. (in Russian)

12. Xue, S., Sun, W., Yang, J., Gao, F., Li, Y., \& Li, Z. (2016). Hidden failure identification and protection of multi-grounding fault in secondary circuit of potential transformer. IEEJ Transactions on Electrical and Electronic Engineering, 11(3), 300-307. https://doi.org/10.1002/tee. 22219

13. Heidary, A., Rouzbehi, K., Radmanesh, H., \& Pou, J. (2020). Voltage transformer ferroresonance: an inhibitor device. IEEE Transactions on Power Delivery, 35(6), 27312733. https:// doi.org/10.1109/TPWRD.2020.3005321

14. Cazacu, E., Ioniță, V., \& Petrescu, L. (2017). An efficient method for investigating the ferroresonance of single-phase iron core devices. In 2017 10th International Symposium on Advanced Topics in Electrical Engineering (ATEE) (pp. 363-368). IEEE. https://doi.org/10.1109/ ATEE.2017.7905167

15. Niu, B., Wu, X., Zhang, G., Ma, F., Tan, D., \& He, S. (2020). Analysis and improvement measures of inductive voltage transformer fault caused by intermittent grounding. Gaoya Dianqi/High Voltage Apparatus, 56(10), 70-74 \& 83. https:/ / doi.org/10.13296/j.1001-1609.hva.2020.10.012

16. Kaczmarek, M. (2016). Secondary current distortion of inductive current transformer in conditions of dips and interruptions of voltage in the power line. Electric Power Systems Research, 137, 1-5. https://doi.org/10. 1016/j.epsr.2016.03.043

17. Popov, M. (2018). General approach for accurate resonance analysis in transformer windings. Electric Power Systems Research, 161, 45-51. https://doi.org/10.1016/ j.epsr.2018.04.002

18. Lesniewska, E., Kaczmarek, M., \& Stano, E. (2021). 3D electromagnetic field analysis applied to evaluate the accuracy of a voltage transformer under distorted voltage. Energies, 14(1), 136. https://doi.org/10.3390/en14010136

19. Etkind, L. (2003). Protection of voltage transformers in 3-35 kV networks. Neutral earthing mode needs to be changed. Electrical Engineering News, (5), 6. http:// news.elteh.ru/arh/2003/23/06.php (in Russian)
20. Hejian, W., Hongtao, L., Tao, G., Jun, J., Hailong, Z., \& Song, J. (2018). Research and application of $10 \mathrm{kV}$ built-in high voltage protection distribution transformer. In 2018 China International Conference on Electricity Distribution (CICED) (pp. 280-284). IEEE. https://doi.org/10. 1109/CICED.2018.8592468

21. Ventruella, D.J. (2018). Transformer fuse sizing the NEC is not the last word. IEEE Transactions on Industry Applications, 55(2), 2173-2180. https://doi.org/10.1109/ TIA.2018.2880145

22. Liang, Z., Zhao, M., Niu, S., Liu, H., Liang, S., \& Guo, Y. (2016). Defects of measures against PT fuse melting in distribution network and research of new measure. Dianli Zidonghua Shebei/Electric Power Automation Equipment, 36(9), 17-24 \& 32. https://doi.org/10.16081/j.issn. 1006-6047.2016.09.003

23. Wang, K., Liu, H., Yang, Q., Yin, L., \& Huang, J. (2019). Impact transient characteristics and selection method of voltage transformer fuse. Energies, 12(4), 737. https://doi.org/10.3390/en12040737

24. Pleşca, A., Dumitrescu, C., Zhang, G., \& Han, D. (2016). Overcurrent protection using a new type of electric fuse. In 2016 International Conference and Exposition on Electrical and Power Engineering (EPE) (pp. 143-146). IEEE. https://doi.org/10.1109/ICEPE.2016.7781321

25. Kim, S., Shin, T., Jeong, S., Kang, H., Son, K., Park, S., ... \& Kim, J. (2020). Modeling and verification of a high voltage fuse for high reliability and safety in electric vehicle. In 2020 IEEE International Symposium on Electromagnetic Compatibility \& Signal/Power Integrity (EMCSI) (pp. 287292). IEEE. https://doi.org/10.1109/EMCSI38923.2020. 9191482

26. Ventruella, D.J. (2020). Transformer fuses - mind the gap. IEEE Transactions on Industry Applications, 56(5), 5670-5677. https:// doi.org/10.1109/TIA.2020.2993523

27. Wright, A., \& Newbery, P.G. (2004). Electric Fuses (3rd ed.). Institution of Electrical Engineers. https://doi. org/10.1049/PBPO049E

28. Wang, M., Chen, W., Li, Y., Zhang, X., Dong, B., Bian, K., ... Deng, F. (2012). A countermeasure to deal with abnormal fusing of high voltage fuse for potential transformer in $35 \mathrm{kV}$ oilfield power distribution system. Dianwang Jishu/Power System Technology, 36(12), 283-288.

29. Torres, E., Fernandez, E., Mazon, A.J., Zamora, I., \& Perez, J.C. (2005). Thermal analysis of medium voltage fuses using the finite element method. In 2005 IEEE Russia Power Tech (pp. 1-5). IEEE. https:// doi.org/10.1109/PTC. 2005.4524671

30. Plesca, A. (2018). Temperature distribution of HBC fuses with asymmetric electric current ratios through fuselinks. Energies, 11(8), 1990. https://doi.org/10.3390/ en11081990

31. International Electrotechnical Commission. (2014). Low-voltage fuses - Part 1: General requirements (IEC Standard No. 60269-1:2006 + AMD1:2009 + AMD2:2014 CSV Consolidated version). https://webstore.iec.ch/publicati on/1234 
32. International Electrotechnical Commission. (2020). High-voltage fuses - Part 1: Current-limiting fuses (IEC Standard No. 60282-1:2020). https://webstore.iec.ch/publicati on/59817
33. Němeček, P. (2009). Proudová ochrana pro vysokonapětové transformátory (CZ patent No. 20024 U1). Úrad průmyslového vlastnictví. https://patents.google.com/ patent/CZ20024U1

\section{До проблеми захисту вимірювальних трансформаторів середньої напруги топкими запобіжниками: аналітичне дослідження}

\section{Євген Байда, Олександр Гречко, Віктор Бугайчук, Роберт Кнапек}

Анотація. Вступ. В електричній мережі середньої напруги 6-35 кВ існує проблема захисту вимірювальних трансформаторів напруги. Це пов' язано з недостатньо ефективним рівнем їх захисту за допомогою топких запобіжників. Останнім часом все частіше з' являються повідомлення щодо аварій, пов' язаних із виходом з ладу вимірювальних трансформаторів напруги не тільки в Україні, а і за кордоном. Актуальним є питання проведення аналітичного дослідження проблеми захисту топкими запобіжниками вимірювальних трансформаторів середньої напруги. Мета. Дослідження конструкцій та характеристик топких запобіжників для вимірювальних трансформаторів середньої напруги для підвищення ефективності їх захисту. Результати. В статті показано, що захист вимірювальних трансформаторів середньої напруги з епоксидною ізоляцією часто забезпечується топкими запобіжниками, у яких номінативним струм топкої вставки є значно більшим за граничнодопустимий тривалий струм первинної обмотки вимірювального трансформатору. Проведено порівняльний аналіз значень струму первинної обмотки вимірювальних трансформаторів середньої напруги зі значеннями номінативних струмів топких вставок запобіжників різних виробників, що представлені на ринку України. Досліджено конструктивні особливості та технічні характеристики топких запобіжників для вимірювальних трансформаторів середньої напруги 3 метою підвищення ефективності їх захисту. Досліджено переваги та недоліки конструкцій топких запобіжників різних виробників, та встановлено, що потребує подальшого вдосконалення конструкції топких запобіжників з метою підвищення ефективності захисту вимірювальних трансформаторів середньої напруги. Обговорення та перспективи подальшого розвитку. Оскільки в Україні потреби у топких запобіжниках для захисту вимірювальних трансформаторів середньої напруги забезпечуються переважно поставками за кордону, то перспективним напрямком подальшого розвитку у цьому напрямі є створення вітчизняної конкурентоспроможної конструкції топкого запобіжника та впровадження його у виробництво.

Ключові слова: вимірювальний трансформатор середньої напруги, топкий запобіжник, захист трансформаторів напруги, струм первинної обмотки вимірювального трансформатору.

\section{NOTES ON CONTRIBUTORS}

\author{
Yevgen Bajda \\ yevhen.baida@khpi.edu.ua
}

Oleksandr Grechko
oleksandr.grechko@khpi.edu.ua

\section{Viktor Buhaichuk}

info@abm-amper.com

\section{Robert Knápek}

knapek@kpbintra.cz
D.Sc., Associate Professor

Department of Electrical Apparatus

National Technical University “Kharkiv Polytechnic Institute", Kharkiv, Ukraine

(iD) https://orcid.org/0000-0003-0297-328X

https:/ / scopus.com/authid/ detail.uri?authorId=57201899539

Ph.D., Associate Professor

Department of Electrical Apparatus

National Technical University “Kharkiv Polytechnic Institute”, Kharkiv, Ukraine

(iD) https://orcid.org/0000-0001-7872-8585

p https://publons.com/researcher/B-1250-2016/

Chairman of the Supervisory Board

ABM Amper Ltd., Kremenchuk, Ukraine

(iD) https:/ / orcid.org/0000-0003-2236-1280

Company Director

KPB Intra s.r.o., Bučovice, Czech Republic

(iD) https:// orcid.org/0000-0001-6043-3922 